\title{
Airport pavement roughness evaluation based on cockpit and center of gravity vertical accelerations
}

\author{
Jorge Braulio Cossío Durán ${ }^{1}$, José Leomar Fernandes Júnior ${ }^{2}$
}

${ }^{1}$ Universidade de São Paulo, Escola de Engenharia de São Carlos, jbcossio@sc.usp.br 2Universidade de São Paulo, Escola de Engenharia de São Carlos, leomar@sc.usp.br

\section{Recebido:}

8 de janeiro de 2019

Aceito para publicação:

17 de junho de 2019

Publicado:

30 de abril de 2020

Editor de área:

Jorge Barbosa Soares

\section{Keywords:}

Airport pavements,

Pavement roughness,

Vertical accelerations,

International roughness index,

Boeing bump index.

\section{Palavras-chaves:}

Pavimentos aeroportuarios, Irregularidade Longitudinal de pavimentos,

Aceleracoes verticais,

Índice internacional de

irregularidade,

Índice boeing de irregularidade.

DOI:10.14295/transportes.v28i1.1932

\begin{abstract}
Rough pavements are generally responsible for vertical accelerations (VA) that can affect the aircraft, increase stopping distance and difficult to read the cockpit instrumentation. The International Roughness Index (IRI) and the Boeing Bump Index (BBI) are currently used to quantify airport pavement roughness and to identify sections that require maintenance and rehabilitation (M\&R) activities. However, these indices were developed only based on dynamic responses of an automobile at $80 \mathrm{~km} / \mathrm{h}$ to the irregularities of road pavements, and on physical characteristics of the irregularities (bump length and height), respectively, without considering the effect of aircraft VA. Additionally, current critical limits, suggested by Sayers \& Karamihas and ANAC, for IRI $(2.0$ and $2.5 \mathrm{~m} / \mathrm{km}$, respectively) and by FAA for $\mathrm{BBI}$ (1.0) can misjudge the real condition of the pavement. This paper evaluates the effect of airport pavement roughness on VA at the aircraft cockpit (VACP) and at the center of gravity (VACG). The ProFAA software was used to compute both indices and to simulate VA in 4 representative aircraft traversing 20 runway profiles at 10 operational speeds varying from 37 to $370 \mathrm{~km} / \mathrm{h}$. Statistical comparisons and regression analyses were carried out. Principal results show that VACP is $50 \%$ higher than VACG and that exceeds the critical limit of $0.40 \mathrm{~g}$ when the IRI and $\mathrm{BBI}$ are higher than $3.7 \mathrm{~m} / \mathrm{km}$ and 0.20 , correspondingly. A case study is also presented to compare these limits and shows that decision-making based on IRI and VA can bring significant differences in the number of $M \& R$ activities.
\end{abstract}

\section{RESUMO}

Pavimentos irregulares são geralmente responsáveis por acelerações verticais (VA) que afetam as aeronaves, aumentam a distância de parada e dificultam a leitura dos instrumentos de navegação na cabine dos pilotos. O International Roughness Index (IRI) e o Boeing Bump Index (BBI) são utilizados atualmente para quantificar a irregularidade longitudinal dos pavimentos aeroportuários e identificar seções que demandam atividades de manutenção e reabilitação (M\&R). Contudo, tais índices baseiam-se apenas nas respostas dinâmicas de um automóvel a $80 \mathrm{~km} / \mathrm{h}$ às irregularidades longitudinais dos pavimentos rodoviários, bem como nas características físicas das irregularidades (comprimento e altura), respectivamente, ignorando o efeito das VA nas aeronaves. Ainda, limites críticos atuais, sugeridos por Sayers \& Karamihas e ANAC para IRI $(2,0$ e 2,5 m/km, respectivamente) e pela FAA para BBI $(1,0)$ podem subestimar a condição real do pavimento. Este artigo avalia o efeito da irregularidade longitudinal nas acelerações na cabine dos pilotos (VACP) e no centro de gravidade (VACG). O software ProFAA permitiu calcular os índices e simular as VA em 4 aeronaves representativas atravessando 20 pistas de pouso e decolagem em 10 velocidades de taxiamento variando de 37 a $370 \mathrm{~km} / \mathrm{h}$. Comparações estatísticas e análises de regressão foram realizadas. Principais resultados mostram que VACP é $50 \%$ maior do que VACG e que ultrapassa o limite critico de $0,40 \mathrm{~g}$ quando o IRI e BBI estão acima de $3,7 \mathrm{~m} / \mathrm{km}$ e 0,20 , respectivamente. Um estudo de caso é também apresentado para comparar esses limites e sugere que a tomada de decisão baseada em IRI e VA pode trazer diferenças significativas na quantidade de atividades de M\&R. 


\section{INTRODUCTION}

Lack of smoothness or roughness is an important distress in airport pavements. Roughness can be defined as the longitudinal deviations of a pavement surface from a true planar surface with characteristic dimensions that affect aircraft dynamics, ride quality and dynamic pavement load, and can cause discomfort, excessive vibrations in the aircraft cockpit, and potential danger to both the aircraft and its passengers (adapted from ASTM, 2018).

The highway industry defines pavement roughness in terms of the ride quality experienced by a passenger (Sayers \& Karamihas, 1998) and according to Sayers, Gillespie, \& Queiroz (1984a, and b), roughness also can induces excessive vibrations in traversing vehicles. In addition, automotive manufacturers design suspension systems to reduce the impact of common surface irregularities and improve overall ride quality. However, the primary purpose of an airplane suspension system is to absorb the energy expended during landing (FAA, 2009). Airplane suspension systems have less capacity to dampen the impact of surface irregularities due to the magnitude of the energy that must be addressed during landing. Thus, airport pavement roughness should be defined in terms of fatigue on aircraft components (increase stress and wear) and/or other factors that may impair the safe operation of the aircraft (cockpit vibrations, excessive g-forces, etc.).

Pavement roughness is also an important indicator for Airport Pavement Management Systems (APMS) (Haas, Hudson \& Falls, 2015). The study of pavement roughness provides valuable information for airport managers and engineers and allows to identifying pavement sections with excessive levels of roughness that are capable to impair the safety of ground operations, cause damage, or increase structural fatigue to an aircraft (ACRP, 2011).

In the airport pavement management field, efforts have been focused on identify and quantify pavement roughness. In most airfields, roughness is often characterized by two indices: the International Roughness Index (IRI) and the Boeing Bump Index (BBI). The World Bank developed the IRI for highway pavements; however, due to the existing analogy with airport pavements it is suggested as well by the National Civil Aviation Agency in Brazil (ANAC). On the other hand, the BBI was developed by The Boeing Company and has been adopted by the Federal Aviation Administration (FAA).

These indices measure a pavement elevation profile accordingly with critical limits for excessive level of roughness. However, they are based on specific mathematical models that do not consider the effect of aircraft dynamic response, such as verticals accelerations generated at the aircraft cockpit and at the center of gravity.

The main objective of this study is to evaluate the effect of airport pavement roughness on aircraft dynamic response in terms of IRI, BBI and vertical accelerations at the aircraft cockpit (VACP) and at the center of gravity (VACG), which may compromise the aircraft safety and the pavement performance.

\section{THE INTERNATIONAL ROUGHNESS INDEX (IRI)}

As stated by Sayers \& Karamihas (1996), the IRI is a profile-based roughness statistic that has become a standard scale on which road roughness information is reported in many countries of the world. According to Gillespie (1992), the IRI is a scale for pavement roughness based on the response of a generic automobile to the roughness of the road surface. The IRI is calculated by 
accumulating the absolute values of the suspension deflection and dividing by the distance traveled. Its mathematical model uses a simulation speed of $80 \mathrm{~km} / \mathrm{h}$, where the simulated suspension motion is linearly accumulated and divided by the length of the profile to compute the IRI. The units of IRI are generally expressed in $\mathrm{m} / \mathrm{km}$ where pavement profiles with IRI near to $0.0 \mathrm{~m} / \mathrm{km}$ are perfectly smooth.

According to Sayers, Gillespie, \& Patterson (1986) and (Sayers, Gillespie, \& Queiroz, 1986), the IRI has been reported to be relevant as an indicator of pavement serviceability, independent of the particular equipment used to measure it, internationally and geographically transferable, and time stable.

In Brazil, the ANAC has been evaluating runway roughness based on IRI since June 2012 due to the existing analogy between highway and airport pavements concepts, materials and construction techniques (ANAC, 2012). In that year the IRI limit for runways was $2.0 \mathrm{~m} / \mathrm{km}$, but nowadays the ANAC suggests that roughness of runways does not exceed $2.5 \mathrm{~m} / \mathrm{km}$ (ANAC, 2019).

Nevertheless, FAA (2013) states that the IRI is not appropriate for airfields pavements since the aircraft pavement characteristics, loading conditions, dynamic movements responding to the pavement surface, and human factors are very different from highway traffic conditions.

\section{THE BOEING BUMP INDEX (BBI)}

In 2002, The Boeing Company developed a simple method called "The Boing Method" to easily detect and repair pavement roughness (Boeing, 2002). It is a simplified procedure based upon operational experience for single bumps describing the general condition of a runway and takes into account the direct effect on aircraft structure through a discrete surface deviation evaluation of the pavement surface measured by a close interval elevation survey.

The survey results are plotted and the discrete bumps are compared to a Boeing criteria developed for commercial aircraft. Once the application of the Boeing Method is a tedious process and usually demands a lot of time, the FAA (FAA, 2009) summarized the Boeing Method and created the Boeing Bump Index.

In general, BBI is analogous to the Boeing Method and is based on three regions of roughness (Acceptable, Excessive, and Unacceptable) where the limit of the acceptable region 1.0. BBI values greater than 1.0 can be fall in the excessive or unacceptable region.

\section{VERTICAL ACCELERATIONS}

Kirk (1973) states that vertical accelerations during large aircraft taxiing due to pavement roughness produce airframe metal fatigue damage and dynamic stressing, as well as discomfort for the crew and passengers (anxiety). Similarly, Ferritto \& Forrest (1976) argues that high vertical accelerations, when transmitted to the cockpit, affect instrument accuracy and decrease the pilot's ability to read the instruments. Moreover, Gerardi (1997) states that rough runways reduce stopping ability and, consequently, can increase the braking distance by about 50\%. In addition, during landing on rough runways, aircraft dynamic loads affect the pilot's ability to maintain constant brake pressure.

In this context, Houbolt (1961) suggests that vertical accelerations should be less than $0.30 \mathrm{~g}$. A NASA research developed by Morris \& Hall (1965a and b) related to pilot complaints due to runway roughness suggest that the maximum vertical acceleration in the cockpit should not 
exceed $0.40 \mathrm{~g}$. However, Alford (1972) argues that vertical accelerations exceeding $0.33 \mathrm{~g}$ are unacceptable and $0.50 \mathrm{~g}$ levels seriously affect pilot performance. Horn (1977) used the $0.40 \mathrm{~g}$ value as a limit of tolerable vertical accelerations. This criterion was also based on human tolerance to vibration proposed by Spangler \& Gerardi (1993). Tests performed by NASA (1992) also supported this value because they have documented that human tolerance to vertical acceleration lies in the range of 0.35 to $0.40 \mathrm{~g}$.

\section{METHOD}

For this study, a sample of 20 runway profiles of asphalt concrete was obtained from an FAA database (FAA, 2018). The profiles totalize approximately 57,000 linear meters of runway pavement and were divided into sections of $100 \mathrm{~m}$ in length, resulting in 570 pavement sections. IRI and BBI were computed by ProFAA for all the sections.

Once critical IRI limits commonly used in airport pavements are equal to $2.5 \mathrm{~m} / \mathrm{km}$ (ANAC, 2019) and $2.0 \mathrm{~m} / \mathrm{km}$ (Sayers \& Karamihas, 1998), two five-category classifications based on such limits are presented to serve as a reference for the analyses performed in this study (see Table 1) and hereinafter are referred to as "CURRENT" classifications. However, these classifications could not represent common critical IRI values found in highway pavements and it is important to highlight that were proposed without the intention to impose or substitute any existent official criteria and/or classification.

Table 1 - Proposed (CURRENT) classifications based on the critical IRI limits of 2.5 and $2.0 \mathrm{~m} / \mathrm{km}$ adopted from ANAC (2018) and from Sayers \& Karamihas (1998), respectively

\begin{tabular}{ccc}
\hline Category & $\begin{array}{c}\text { IRI }(\mathrm{m} / \mathbf{k m}) \\
\text { SAYERS }\end{array}$ & $\begin{array}{c}\text { IRI }(\mathrm{m} / \mathbf{k m}) \\
\text { ANAC }\end{array}$ \\
\hline Very Good & $<0.5$ & $<1.0$ \\
Good & 0.5 to 1.0 & 1.0 to 1.5 \\
Regular & 1.0 to 1.5 & 1.5 to 2.0 \\
Poor & 1.5 to 2.0 & 2.0 to 2.5 \\
Very Poor & $>2.0$ & $>2.5$ \\
\hline
\end{tabular}

Regarding the simulation criteria for vertical accelerations, the ProFAA software provides a default library with four representative commercial aircraft to simulate aircraft dynamic responses. Although most of them are no longer in operation, they approximates to the behavior of analogous aircraft once aircraft dynamic response depends predominantly on aircraft weight, axle spacing, landing gear configuration, and operational speed.

Thus, simulations were carried out according to four aircraft classes:

- Class I (Less than 70,000 kg - DC-9-41/E-190AR);

- Class II (70,000 to 140,000 kg - B727-100/B737-800/MAX8);

- Class III (140,000 to 210,000 kg - DC-10CF/B767-300ER); and,

- Class IV (greater than 210,000 kg - B747SP/B747-400).

In the same context, ten constant taxi speeds ranging from 20 to 200 knots ( 37 to $370 \mathrm{~km} / \mathrm{h}$ ) were considered for this study, accordingly with the following classification:

- Very Low (20 and 40 knots/37 and $74 \mathrm{~km} / \mathrm{h}$ );

- Low (60 and 80 knots/111 and $148 \mathrm{~km} / \mathrm{h}$ );

- Medium (100 and 120 knots/185 and $222 \mathrm{~km} / \mathrm{h}$ ); 
- High (140 and 160 knots/259 and $296 \mathrm{~km} / \mathrm{h}$ ); and,

- Very High (180 and 200 knots/333 and $370 \mathrm{~km} / \mathrm{h}$ ).

Furthermore, simulations in ProFAA were carried out by representative aircraft class, attending the following parameters: Sample Spacing of $0.0255248 \mathrm{~m}$; Averaging Distance of $100 \mathrm{~m}$; Smoothing Distance of 100 m; Aircraft Speed from 20 to 200 knots; Airframe Damping Factor equal to 0.0250; Aircraft Types (FAA library - DC-9/B-727/DC-10/B-747); 10 Number of Modes, and zero meter of Cutting Length at Ends.

Consequently, the elevation data from the 20 runway profiles were entered as input into the software ProFAA to simulate VACP and VACG. Simulations were carried out for the 570 sections and for each aircraft class (four classes) traversing each elevation profile (20 runways) at each discrete speed ( 37 to $370 \mathrm{~km} / \mathrm{h}$ ).

Statistical analysis involves Pearson correlations between IRI vs. BBI, VACP vs. VACG and between them, as well as linear regression analysis where IRI and VACP are considered independent variables. Vertical accelerations were also analyzed in terms of operational speed and results were presented by maximum or peak values and by aircraft class. Additionally, regression models are presented in another table where the last two columns correspond to the IRI and BBI estimated when vertical accelerations reach $0.35 \mathrm{~g}$ and $0.40 \mathrm{~g}$, respectively. This approach allowed identifying the lower value that reached such limit and consequently was considered critical value.

Finally, a case study is presented as an application example. The case study consists of an airport network comprised of nine medium and large airport runways of asphalt concrete, currently in operation. Measurements were performed at the end of 2013 for the whole network during the night and under cloudy weather. It was used a multi-laser profiler vehicle to measure the elevation profile and to compute the IRI in $\mathrm{m} / \mathrm{km}$. Each runway profile was divided into sections of $100 \mathrm{~m}$ in length, resulting in 172 pavement sections. To maintain the confidentiality of the data the runways were named alphabetically from A to I.

A supplementary table was presented to show the number of pavement sections that fall into each IRI category of the three classifications: SAYERS (IRI limit of $2.0 \mathrm{~m} / \mathrm{km}$ ), ANAC (IRI limit of $2.5 \mathrm{~m} / \mathrm{km}$ ) and "ALTERNATIVE" (IRI limit based on the critical model given by the regression analysis), as well as the corresponding percentage compared to the total sections in the network.

\section{RESULTS}

\subsection{IRI vs. BBI}

Results indicate strong and positive correlation between IRI and BBI where $r=0.68, n=570$, and $\mathrm{p}<0.001$. Figure 1 shows the relationship between both indices. As can be seen, there was a strong, non-linear, and positive correlation between IRI and BBI, with an R-squared value of 0.72 .

Furthermore, the tendency line of the equation indicates that BBI is approximately 0.10 times the IRI. This means that for a BBI value to reach or exceed the acceptable zone (BBI $\geq 1$ ) the IRI value would have to be approximately $10 \mathrm{~m} / \mathrm{km}$. The model of the regression analysis was significant (P-value $<0.01$ ) and indicate very strong and positive correlation with a coefficient of 0.1008 , and R-squared value equal to 0.87 . However, it is clear that, in general, IRI values higher than $5 \mathrm{~m} / \mathrm{km}$ do not represent the reality of most runways and therefore this may 
be a sign that point out the necessity to evaluate and adjust the scale of the BBI index. Small BBI values can occur due to the mathematical model process itself when the index is calculated. It is probably that the imaginary straight length used by the Boeing method is too short to comprise many bump length and bump height configurations.

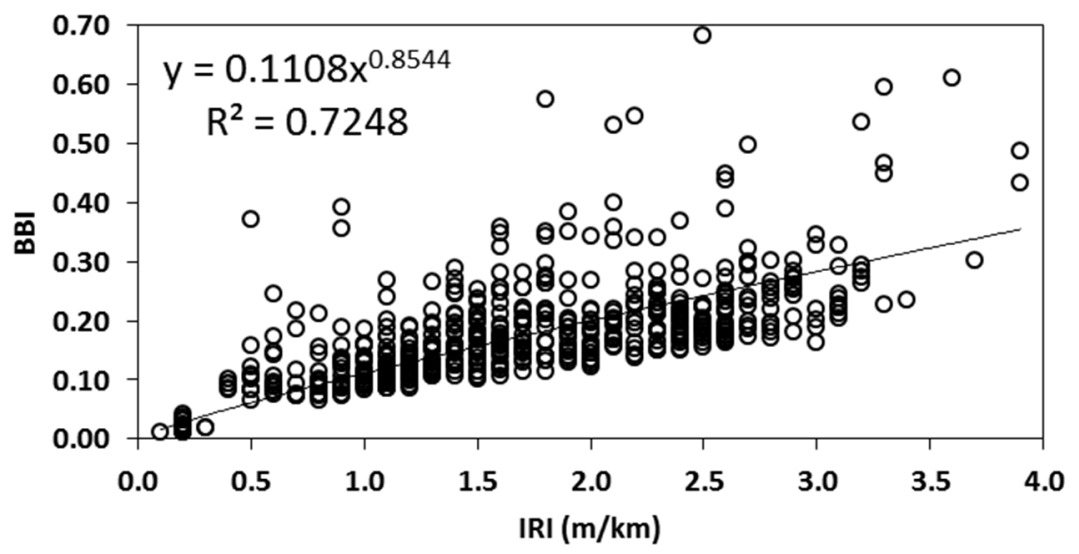

Figure 1. IRI vs BBI for sections of $100 \mathrm{~m}$ in length

Furthermore, the tendency line of the equation indicates that BBI is approximately 0.10 times the IRI. This means that for a BBI value to reach or exceed the acceptable zone (BBI $\geq 1$ ) the IRI value would have to be approximately $10 \mathrm{~m} / \mathrm{km}$. The model of the regression analysis was significant (P-value $<0.01$ ) and indicate very strong and positive correlation with a coefficient of 0.1008 , and R-squared value equal to 0.87 . However, it is clear that, in general, IRI values higher than $5 \mathrm{~m} / \mathrm{km}$ do not represent the reality of most runways and therefore this may be a sign that point out the necessity to evaluate and adjust the scale of the BBI index. Small BBI values can occur due to the mathematical model process itself when the index is calculated. It is probably that the imaginary straight length used by the Boeing method is too short to comprise many bump length and bump height configurations.

\subsection{Vertical Accelerations vs. IRI}

Figure 2 plots VACP and VACG as a function of IRI. Values 3.5, 3.8, and $4.0 \mathrm{~m} / \mathrm{km}$ are missing values. The red dashed line indicates the limit of acceptable accelerations $(0.40 \mathrm{~g})$.

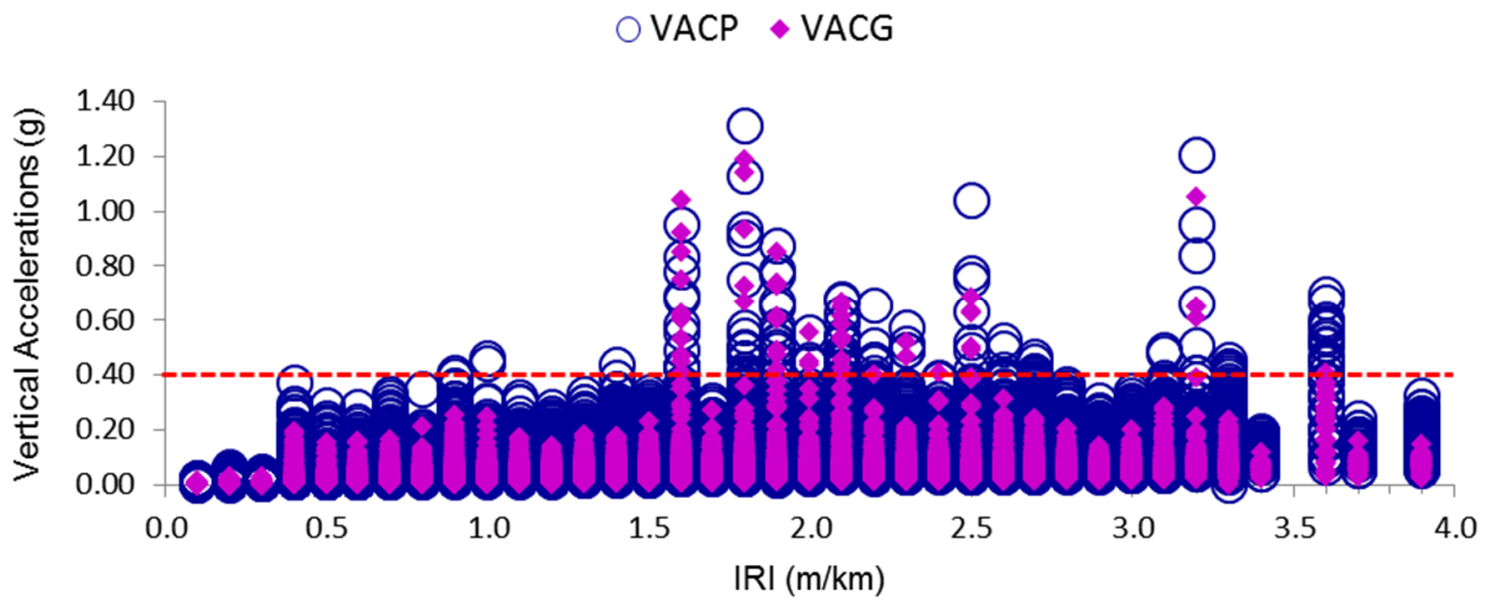

Figure 2. Vertical accelerations distribution based on IRI for sections of $100 \mathrm{~m}$ in length 
It is evident that most of the VACP are higher than VACG, suggesting that the aircraft cockpit is more sensible to excessive vertical accelerations than the center of gravity. Furthermore, it can be observed that excessive accelerations at the cockpit and at the center of gravity occurred principally between 1.6 and $2.5 \mathrm{~m} / \mathrm{km}$, but also at $3.2 \mathrm{~m} / \mathrm{km}$, once can exist infinite roughness configurations (bump length and height) that are capable of generating excessive vertical accelerations.

However, less than $1 \%$ of the VACP values in the database were higher than $0.40 \mathrm{~g}$. For this reason, it is extremely important that, in a network level APMS, the evaluation of the pavement profile is based both on vertical accelerations and IRI, because of the advantage to identifying quickly critical sections that can be then addressed to the project level to establishing the M\&R activities.

\subsection{VACP vS. VACG}

Table 2 presents the correlation results between VACP and VACG, indicating positive and strong and moderate correlation. All of them were significant, $r=0.91, n=22800, p<0.001$.

Table 2 - Pearson correlation between VACP and VACG by aircraft class

\begin{tabular}{|c|c|c|c|c|c|c|c|c|c|}
\hline & & \multicolumn{2}{|c|}{ Class I } & \multicolumn{2}{|c|}{ Class II } & \multicolumn{2}{|c|}{ Class III } & \multicolumn{2}{|c|}{ Class IV } \\
\hline & & VACP & VACG & VACP & VACG & VACP & VACG & VACP & VACG \\
\hline \multirow{2}{*}{ Class I } & VACP & 1 & & & & & & & \\
\hline & VACG & 0.89 & 1 & & & & & & \\
\hline \multirow{2}{*}{ Class II } & VACP & 0.88 & 0.82 & 1 & & & & & \\
\hline & VACG & 0.85 & 0.90 & 0.93 & 1 & & & & \\
\hline \multirow{2}{*}{ Class III } & VACP & 0.65 & 0.46 & 0.79 & 0.65 & 1 & & & \\
\hline & VACG & 0.65 & 0.47 & 0.76 & 0.66 & 0.95 & 1 & & \\
\hline \multirow{2}{*}{ Class IV } & VACP & 0.65 & 0.48 & 0.79 & 0.64 & 0.90 & 0.86 & 1 & \\
\hline & VACG & 0.68 & 0.53 & 0.78 & 0.68 & 0.87 & 0.89 & 0.94 & 1 \\
\hline
\end{tabular}

As can be seen, the stronger correlations are in aircraft Classes I vs. II, as well as in Classes III vs. IV (shaded areas). Correlations in Class I vs. Class III and IV show moderate correlation. However, Class II vs. Class III and IV shows both strong and moderate correlation for VACP and VACG, respectively. In the same context, regression analysis between vertical accelerations indicates extremely strong and positive correlation with P-value $<0.05$. In general, vertical accelerations at the cockpit result $49 \%$ higher than vertical accelerations at the center of gravity, as shown in Table 3.

Table 3 - Pearson correlation between VACP and VACG by aircraft class

\begin{tabular}{cccccc}
\hline Dependent Variable & Independent Variable & Coefficient & Sig. & $\mathrm{R}^{2}$ & Adjusted R \\
\hline VACG & VACP & 0.49 & $<0.01$ & 0.99 & 0.99 \\
VACG Class I & VACP Class I & 0.45 & $<0.01$ & 0.99 & 0.98 \\
VACG Class II & VACP Class II & 0.51 & $<0.01$ & 0.99 & 0.99 \\
VACG Class III & VACP Class III & 0.50 & $<0.01$ & 0.99 & 0.99 \\
VACG Class IV & VACP Class IV & 0.53 & $<0.01$ & 0.99 & 0.99 \\
\hline
\end{tabular}

Table 3 shows that the coefficient of Class II (0.51) is about $13 \%$ higher than Class I (0.45). Similarly, the coefficient of Class IV (0.53) is approximately $18 \%$ higher than Class I, and just $6 \%$ higher than Class III (0.50). The Class II coefficient results just $2 \%$ higher than the Class III. 
Once vertical accelerations at the cockpit are about twice than accelerations at the center of gravity and consequently are considered critical, subsequent analyses of results can be focused on the aircraft cockpit behavior.

\subsection{Vertical Accelerations vs. Speed}

Figure 3 plots maximum vertical acceleration versus speed involving all aircraft classes. As can be seen, accelerations increase as speed increases and VACP are higher than VACG. However, it can be also observed that from 40 to 120 knots VACP is about twice or more higher than VACG. From 140 knots, VACP and VACG tend to be approximately equal, with little variations about $10 \%$. Additionally, it can be seen that VACP and VACG reach the critical limit of $0.40 \mathrm{~g}$ at 80 knots (about $150 \mathrm{~km} / \mathrm{h}$ ) and $140 \mathrm{knots}$ (about $260 \mathrm{~km} / \mathrm{h}$ - rotation speed), respectively.

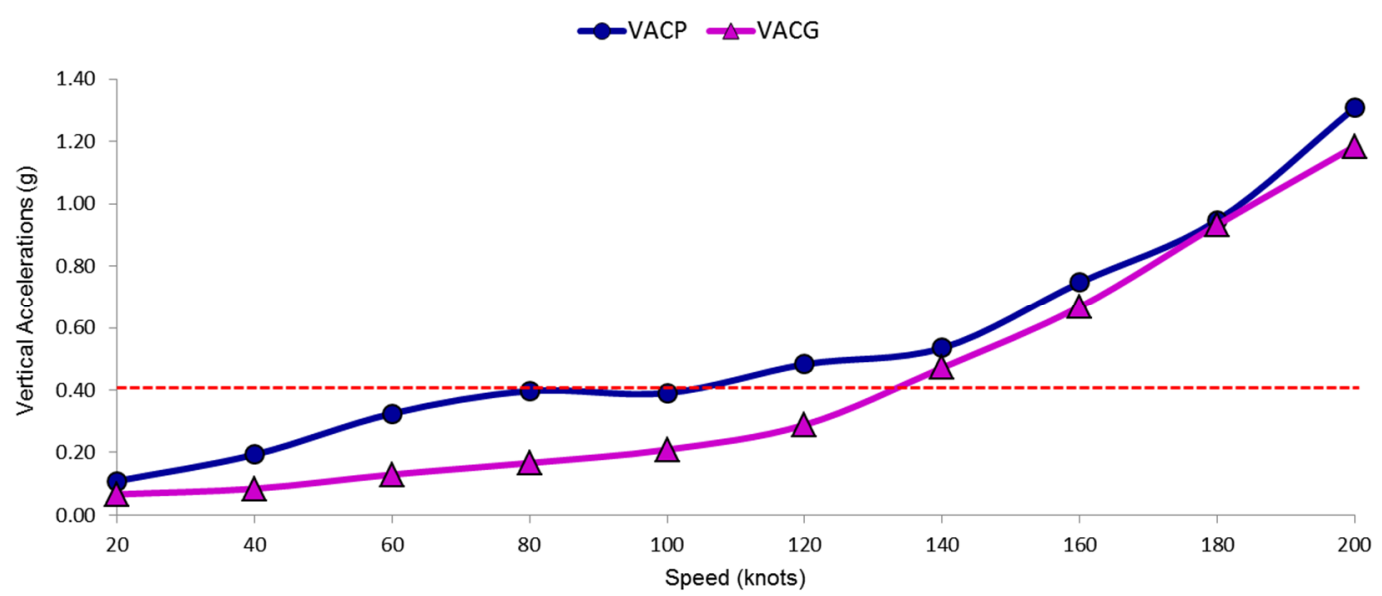

Figure 3. Vertical accelerations by operational speed in knots

\subsection{Vertical Accelerations vs. Roughness Indices}

Results in Table 4 indicate that the correlation between vertical accelerations and pavement roughness indices were significant $(\mathrm{P}$-value $<0.05)$ and that there are good and positive correlations for both roughness indices.

Table 4 - Pearson correlation coefficients for vertical accelerations and roughness indices, by aircraft class

\begin{tabular}{ccccccccccc}
\hline & \multicolumn{2}{c}{ Overall } & \multicolumn{2}{c}{ Class I } & \multicolumn{2}{c}{ Class II } & \multicolumn{2}{c}{ Class III } & \multicolumn{2}{c}{ Class IV } \\
\hline & VACP & VACG & VACP & VACG & VACP & VACG & VACP & VACG & VACP & VACG \\
\hline IRI & 0.52 & 0.50 & 0.65 & 0.57 & 0.54 & 0.52 & 0.50 & 0.49 & 0.44 & 0.45 \\
BBI & 0.60 & 0.56 & 0.62 & 0.58 & 0.64 & 0.59 & 0.62 & 0.57 & 0.58 & 0.55 \\
\hline
\end{tabular}

As can be seen, the average coefficient for IRI is 0.50 while the average coefficient for BBI is 0.60 ; consequently, BBI shows about $20 \%$ higher correlation than IRI. In addition, it can be observed that the lower correlation coefficients for IRI corresponds to the aircraft class IV and result approximately $10 \%$ lower than the average. Conversely, correlation coefficients for BBI remain relatively constant in all aircraft classes, varying approximately $3.5 \%$ with respect to the average. In the context of vertical accelerations, BBI shows a higher correlation than IRI.

Table 5 present the results of the regression analysis between IRI and BBI as independent variable and VACP as dependent variable, respectively. Results for both indices indicates very strong and positive coefficient of determination. All the models were significant (P-value $<0.05)$. 
For IRI, it can be observed that the critical situation occurs in the model VACP MAX that considers peak vertical accelerations at the aircraft cockpit. It means that vertical accelerations become to be critical $(0.35 \mathrm{~g})$ when the IRI is $3.4 \mathrm{~m} / \mathrm{km}$ and exceeds the critical limit when it is above $3.7 \mathrm{~m} / \mathrm{km}$. On the other hand, results for BBI shows that the average $\mathrm{R}^{2}$ for $\mathrm{BBI}$ is 0.94 , about $11 \%$ higher than IRI. In this case, the critical situation also occurs in the model VACP MAX and means that vertical accelerations exceed $0.35 \mathrm{~g}$ when BBI is 0.20 .

Evidently, a BBI value equal or near to 0.20 is very low and falls into the Acceptable region of the BBI classification. Despising the maximum accelerations model, the average BBI to reach $0.40 \mathrm{~g}$ is 0.8 . In this context, pavement sections with BBI values that fall into the acceptable region probably are subjected to high accelerations that reach or exceed $0.40 \mathrm{~g}$.

Table 5 - Linear regression analyses for VACP vs. IRI; by overall, RMS, MAX, and aircraft class

\begin{tabular}{|c|c|c|c|c|c|}
\hline Dependent Variable & $\begin{array}{c}\text { Independent } \\
\text { Variable }\end{array}$ & Equation & $\mathbf{R}^{2}$ & $\begin{array}{c}\text { IRI/BBI to reach } \\
0.35 \mathrm{~g} \\
\end{array}$ & $\begin{array}{l}\text { IRI/BBI to reach } \\
0.40 \mathrm{~g} \\
\end{array}$ \\
\hline VACP Overall & IRI & VACP $=(0.1563 * \mid R I)^{2}$ & 0.85 & 3.8 & 4.0 \\
\hline VACP RMS & IRI & VACP $=(0.1425 * I R I)^{2}$ & 0.85 & 4.2 & 4.4 \\
\hline VACP MAX & IRI & $\operatorname{VACP}=(0.1729 * \mid \mathrm{RI})^{2}$ & 0.78 & 3.4 & 3.7 \\
\hline VACP Class I & IRI & VACP $=(0.1697 * \mid R I)^{2}$ & 0.89 & 3.5 & 3.7 \\
\hline VACP Class II & IRI & VACP $=(0.1507 * \mid R I)^{2}$ & 0.86 & 3.9 & 4.2 \\
\hline VACP Class III & IRI & $\operatorname{VACP}=(0.1664 *|R|)^{2}$ & 0.85 & 3.6 & 3.8 \\
\hline VACP Class IV & $|R|$ & $\operatorname{VACP}=(0.1385 *|R|)^{2}$ & 0.83 & 4.3 & 4.6 \\
\hline VACP & $\mathrm{BBI}$ & VACP $=(1.2970)^{2} * \mathrm{BBI}$ & 0.91 & 0.2 & 0.2 \\
\hline VACP RMS & $\mathrm{BBI}$ & $\mathrm{VACP}=(0.7194)^{2 *} \mathrm{BBI}$ & 0.99 & 0.7 & 0.8 \\
\hline VACP MAX & $\mathrm{BBI}$ & $\mathrm{VACP}=(1.2970)^{2} * \mathrm{BBI}$ & 0.91 & 0.2 & 0.2 \\
\hline VACP Class I & $\mathrm{BBI}$ & $\mathrm{VACP}=(0.7690)^{2} * \mathrm{BBI}$ & 0.94 & 0.6 & 0.7 \\
\hline VACP Class II & $\mathrm{BBI}$ & $\mathrm{VACP}=(0.6917)^{2} * \mathrm{BBI}$ & 0.94 & 0.7 & 0.8 \\
\hline VACP Class III & $\mathrm{BBI}$ & VACP $=(0.7665)^{2} * \mathrm{BBI}$ & 0.93 & 0.6 & 0.7 \\
\hline VACP Class IV & $\mathrm{BBI}$ & VACP $=(0.6424)^{2} * \mathrm{BBI}$ & 0.93 & 0.8 & 1.0 \\
\hline VACG & IRI & VACG $=(0.1101 * I R I)^{2}$ & 0.84 & 5.4 & 5.7 \\
\hline VACG RMS & IRI & VACG $=(0.1017 *|R|)^{2}$ & 0.84 & 5.8 & 6.2 \\
\hline VACG MAX & $\mid \mathrm{RI}$ & VACG $=(0.1249 * I R I)^{2}$ & 0.73 & 4.7 & 5.1 \\
\hline VACG Class I & IRI & VACG $=(0.1137 * I R I)^{2}$ & 0.87 & 5.2 & 5.6 \\
\hline VACG Class II & IRI & VACG $=(0.1075 * I R I)^{2}$ & 0.84 & 5.5 & 5.9 \\
\hline VACG Class III & IRI & VACG $=(0.1177 * I R I)^{2}$ & 0.84 & 5.0 & 5.4 \\
\hline VACG Class IV & $|R|$ & VACG $=(0.1014 *|R|)^{2}$ & 0.84 & 5.8 & 6.2 \\
\hline VACG & $\mathrm{BBI}$ & VACG $=(0.5038)^{2 * B B I}$ & 0.92 & 1.4 & 1.6 \\
\hline VACG RMS & $\mathrm{BBI}$ & VACG $=(0.5322)^{2 *} \mathrm{BBI}$ & 0.97 & 1.2 & 1.4 \\
\hline VACG MAX & $\mathrm{BBI}$ & VACG $=(1.0972)^{2} * \mathrm{BBI}$ & 0.84 & 0.3 & 0.3 \\
\hline VACG Class I & $\mathrm{BBI}$ & VACP $=(0.5167)^{2} * \mathrm{BBI}$ & 0.93 & 1.3 & 1.5 \\
\hline VACG Class II & $\mathrm{BBI}$ & VACP $=(0.4902)^{2} * \mathrm{BBI}$ & 0.91 & 1.5 & 1.7 \\
\hline VACG Class III & $\mathrm{BBI}$ & VACP $=(0.5400)^{2} * \mathrm{BBI}$ & 0.92 & 1.2 & 1.4 \\
\hline VACG Class IV & $\mathrm{BBI}$ & VACP $=(0.4681)^{2} * \mathrm{BBI}$ & 0.92 & 1.6 & 1.8 \\
\hline
\end{tabular}

Similarly, VACG results for IRI show that the critical situation also occurs in the model VACG MAX that considers peak vertical accelerations at the center of gravity. In this case, vertical accelerations become to be critical ( $0.35 \mathrm{~g}$ ) when IRI is $4.7 \mathrm{~m} / \mathrm{km}$ and exceeds the critical limit when it is above $5.1 \mathrm{~m} / \mathrm{km}$. Results for BBI also indicates that the critical situation occurs in the model VACG MAX, but this time accelerations exceeding $0.40 \mathrm{~g}$ occur when $\mathrm{BBI}$ is 0.3 . Despising the maximum acceleration model the average $\mathrm{BBI}$ to reach $0.40 \mathrm{~g}$ is 1.6 . Thus, from a point of view of VACP and VACG, it is clear the necessity to evaluate and adjust the scale of the BBI index. The critical models for vertical accelerations are highlighted in Table 5. However, the two models indicated by a red line show the critical models for VACP and VACG based on IRI and BBI, respectively. As can be seen, VACP is more critical than VACG. 


\subsection{Alternative Classification}

Table 6 is a proposed classification based on the critical limit obtained from the regression analysis for VACP (IRI=3.7 m/km). The idea of an alternative classification is to provide a technical criterion to support airport managers and engineers, from a network level point of view, in the decision-making process of an APMS.

Table 6 - Alternative classification based on the critical IRI limit of $3.7 \mathrm{~m} / \mathrm{km}$ given by the VACP model

\begin{tabular}{cc}
\hline Category & $\begin{array}{c}\text { IRI }(\mathbf{m} / \mathbf{k m}) \\
\text { VACP }\end{array}$ \\
\hline Very Good & $<1.8$ \\
Good & 1.8 to 2.6 \\
Regular & 2.6 to 3.2 \\
Poor & 3.2 to 3.7 \\
Very Poor & $>3.7$ \\
\hline
\end{tabular}

\subsection{Case Study}

The airport network has $815,400 \mathrm{~m}^{2}$ of asphalt pavement distributed in the nine runways with lengths ranging from 1300 to $3000 \mathrm{~m}$ and IRI Profile values varying from 1.19 and $4.01 \mathrm{~m} / \mathrm{km}$. Based on the same colored scale shown in Table 6, the following Figure 4 illustrates the five IRI categories (Very Good, Good, Regular, Poor, and Very Poor) for the three IRI classifications discussed before (SAYERS, ANAC and VACP), by pavement sections and for the nine runways in the study, respectively.

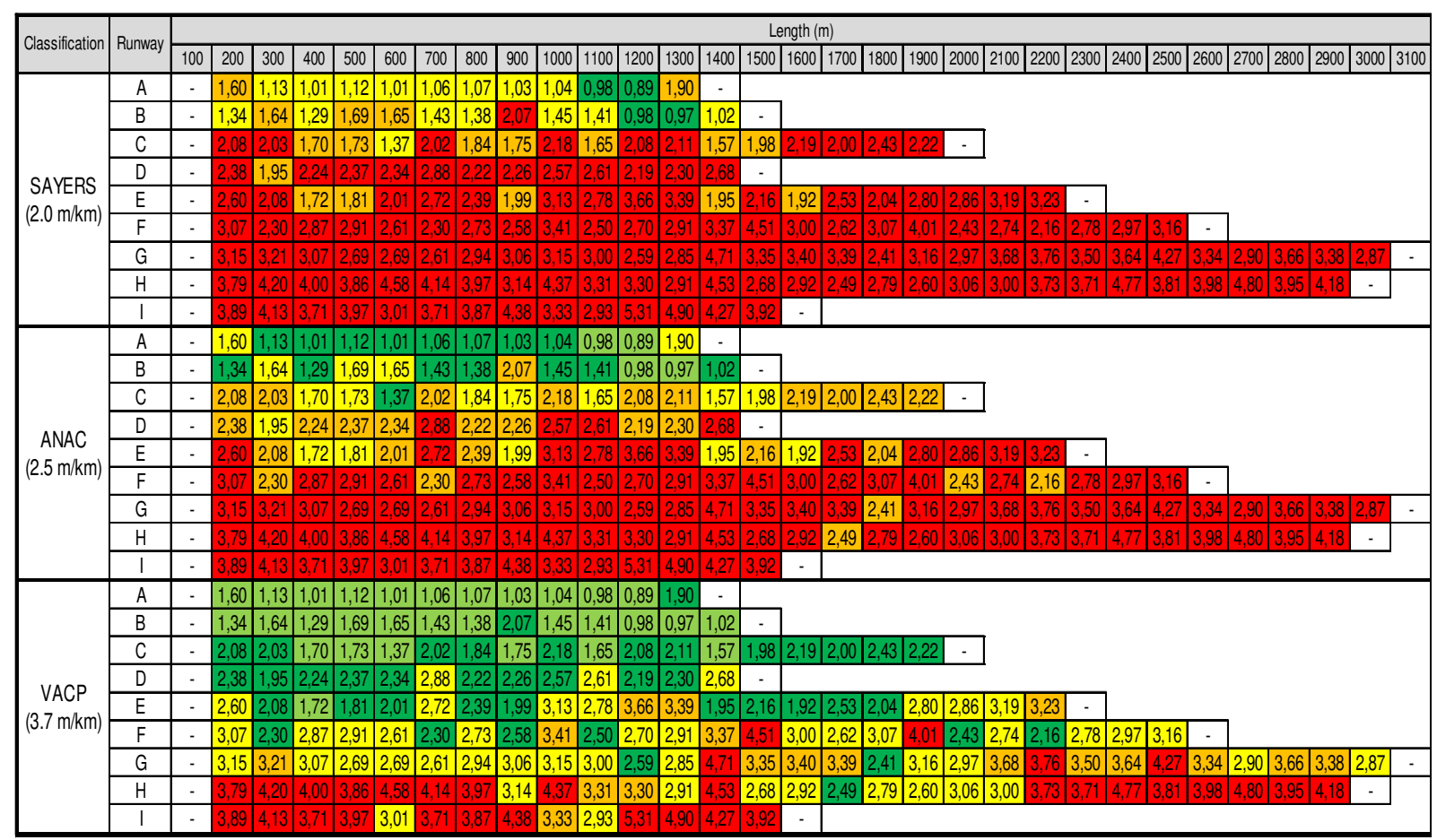

Figure 4. IRI classifications for the airport network

As can be seen, the five classifications were distributed vertically in the table and within each classification there are the nine runways of the airport network. Once the runways were named and ordered according to the severity of the pavement roughness, it is easy to see that as the 
runways are presented in each classification, the roughness severity increases. Note that in the first classification (SAYERS), pavement sections are predominantly "Very Poor" (characterized by the color red). It means that as the critical limits established by the classifications increases, the number of "red" sections decreases significantly. Table 7 allows visualizing this behavior numerically.

Table 7 - Maintenance and Rehabilitation needs by IRI classification

\begin{tabular}{c|cc|cc|cc}
\hline \multirow{2}{*}{ IRI Categories } & \multicolumn{4}{|c|}{ Current Classifications } & \multicolumn{2}{c}{$\begin{array}{c}\text { Alternative } \\
\text { Classification }\end{array}$} \\
\cline { 2 - 7 } & \multicolumn{2}{|c|}{ SAYERS } & \multicolumn{2}{c|}{ ANAC } & \multicolumn{2}{c}{ VACP } \\
Very Good & 0 & $0 \%$ & 4 & $2 \%$ & 30 & $17 \%$ \\
Good & 4 & $2 \%$ & 16 & $9 \%$ & 43 & $25 \%$ \\
Regular & 16 & $9 \%$ & 18 & $10 \%$ & 48 & $28 \%$ \\
Poor & 18 & $10 \%$ & 30 & $17 \%$ & 18 & $10 \%$ \\
Very Poor & 134 & $78 \%$ & 104 & $60 \%$ & 33 & $19 \%$ \\
\hline Total & 172 & $100 \%$ & 172 & $100 \%$ & 172 & $100 \%$ \\
\hline
\end{tabular}

Table 7 shows the number of pavement sections that fall into each IRI category for both current and alternative classifications, as well as the corresponding percentage compared to the 172 sections in the network. Starting with Sayer's classification, it is easy to see that most of the airport network (78\%) has a "Very Poor" condition in terms of pavement roughness. Moreover, $19 \%$ of the sections are also concentrated in the categories "Regular" and "Poor". Although many sections can produce or generate excessive vertical accelerations due to the severity of roughness, there are also sections that are far from reaching critical limits. So, from a vertical acceleration point of view, it is evident that Sayer's classification imposes an IRI limit that misjudges the real condition of the pavement sections.

Conversely, the ANAC classification based on the limit of $2.5 \mathrm{~m} / \mathrm{km}$ shows that the number of sections in a "Very Poor" condition decreases to $60 \%$ and that another $36 \%$ was distributed along the intermediary categories. However, there are still various sections that are being misjudged and the number of "Very Poor" sections in this classification decreases only about 23\% respect to the number of "Very Poor" sections in Sayer's classification. In this context, it is clear that the problem in both current classifications is that critical limits of IRI force the sections to assume an extremely bad condition when the roughness that characterizes them still does not have the capacity to negatively affect the aircraft structure and the navigation instruments, nor jeopardize the operational safety.

On the other hand, the alternative classification shows a reduction in the number of "Very Poor" sections to 19\%. It means that while the use of current classifications considers that approximately $70 \%$ of the airport network is in "Very Poor" conditions, the alternative classification allows a better selection based on vertical accelerations, indicating that only about $23 \%$ of the network is in "Very Poor" condition. In other words, decision-making based on the alternative classification for this case study reduces up $67 \%$ the needs for immediate rehabilitation compared to the current classifications.

\section{CONCLUSIONS}

This study aimed to evaluate the effect of airport pavement roughness on aircraft dynamic response in terms of IRI, BBI and vertical accelerations at the aircraft cockpit (VACP) and at the 
center of gravity (VACP), which may compromise the aircraft safety and the pavement performance. The main conclusions are the following:

- Regression analysis indicates that BBI was approximately 0.10 times the IRI. This means that for a BBI value to reach or exceed the acceptable zone (BBI $\geq 1.0)$ the IRI value would have to be greater than $10.0 \mathrm{~m} / \mathrm{km}$. Thus, it is probable that the scale of the Boeing Bump Method needs to be evaluated and adjusted, in order to take into account the influence of vertical accelerations;

- It was observed that VACP become to be critical $(>0.35 \mathrm{~g})$ when IRI is $3.4 \mathrm{~m} / \mathrm{km}$ and when $\mathrm{BBI}$ is 0.20 (with $\mathrm{BBI}=0.20$ falling into the Acceptable region of the BBI classification); and exceeds the critical limit of $0.40 \mathrm{~g}$ when they are above $3.7 \mathrm{~m} / \mathrm{km}$ and 0.20 , respectively. On the other hand, vertical accelerations at the center of gravity become to be critical only when IRI is $4.7 \mathrm{~m} / \mathrm{km}$ and when $\mathrm{BBI}$ is 0.30 (with $\mathrm{BBI}=0.30$ also falling into the Acceptable region of the BBI classification); and exceeds the critical limit when they are above $5.1 \mathrm{~m} / \mathrm{km}$ and 0.30 , respectively. Consequently, it is evident that the most critical model was VACP. Furthermore, there is a possibility that some pavement sections with BBI values falling into the acceptable region are subjected to excessive accelerations and therefore, there is a need to evaluate and adjust such index in order to take into account the influence of vertical accelerations.

- Vertical accelerations decrease as aircraft weight increases. However, they increase as speed increases. Vertical accelerations in the aircraft cockpit are higher than in the center of gravity, mainly between 74 to $222 \mathrm{~km} / \mathrm{h}$, where variations of more than the double were found. Furthermore, VACP and VACG exceed the critical limit of $0.40 \mathrm{~g}$ at 148 and $259 \mathrm{~km} / \mathrm{h}$, respectively. In general, it is concluded that VACP are more critical than those occurred at the center of gravity. Regression analysis showed that VACP are about $50 \%$ higher than VACG. Therefore, it is suggested that further studies focused principally on the aircraft cockpit;

- As can be seen, the case study shows that decision-making based on IRI and VA can bring significant differences in the number of M\&R activities. Consequently, it is recommended the use of the alternative classification in airport pavements to help airport managers and engineers to make decisions through an additional technical criterion, in order to reduce the number of unnecessary maintenance and rehabilitation treatments. However, the use and results interpretation by the use of any classification (current or alternative) presented in this study is the responsibility of the user. Also, the choice of the best or ideal classifications will depend directly on the technical needs of a specific airport network or runway as well as on the priorities established by airport managers, engineers, and those involved in the decision-making process;

- Finally, it is extremely important to keep in mind that the use of any of these alternative classifications should be accompanied by the evaluation of the pavement elevation profile and that simulations of vertical accelerations by ProFAA software also should be carried out.

\section{ACKNOWLEDGEMENTS}

The authors acknowledge to CAPES (Brazilian Federal Agency for Support and Evaluation of Graduate Education) for their financial support. 


\section{REFERENCES}

ASTM. (2018). Standard Practice for Computing International Roughness Index of Roads from Longitudinal Profile Measurements. ASTM E1926 - 08. American Society of Testing and Materials. USA. DOI: 10.1520/E1926-08R15.

ACRP. (2011). Common Airport Pavement Maintenance Practices. A Synthesis of Airport Practice. ACRP Synthesis No. 22. Airport Cooperative Research Program. Transportation Research Board. USA. ISBN 978-0-309-14334-9

Alford, W. (1972). Functional requirements of airport pavements, an airline pilots viewpoint. Second Annual Short Course in Structural Design of Airport Pavements. University of Illinois. Urbana, Illinois, USA.

ANAC. (2019). Aeródromos - Operação, Manutenção e Resposta à Emergência. RBAC No. 153. Emenda No.04. Agência Nacional de Aviação Civil. Brasil.

ANAC. (2012). Aeródromos - Operação, Manutenção e Resposta à Emergência. RBAC No. 153. Emenda No.00. Agência Nacional de Aviação Civil. Brasil.

Boeing. (2002). Runway Roughness Measurement, Quantification, and Application - The Boeing Method. Document No. D681746. Boeing Commercial Airplane Group. Airport Technology Organization (B-B210). Seattle, Washington, USA.

FAA. (2018). Federal Aviation Administration. Retrieved September 29, 2018, from Airport Pavement Roughness Research: http://www.airporttech.tc.faa.gov/Airport-Pavement/Nondestructive-Pavement-Testing/AirportPavementRoughnessResearch.

FAA. (2013). Airport Pavement 10-Year R\&D Program. Aviation Research Division. Airport Technology R\&D Branch. Federal Aviation Administration Technical Center. Atlantic City, New Jersey, USA.

FAA. (2009). Guidelines and Procedures for Measuring Airfield Pavement Roughness. Advisory Circular No. 150/5380-9. U.S. Department of Transportation. Federal Aviation Administration. USA.

Ferritto, J. M., \& Forrest, J. B. (1976). Effects of Pavement Roughness on Naval Air Operations. Technical Report TR-846. Naval Facilities Engineering Command. Civil Engineering Laboratory. Naval Construction Battalion Center, CA. Alexandria, VA, USA.

Gerardi, A. G. (1997). The effect of runway roughness on aircraft operations. Aircraft/Pavement Technology In the Midst of Change. Seattle, Washington, USA. ISBN: 0784402868.

Gillespie, T. D. (1992). Everything You Always Wanted to Know about the IRI, But Were Afraid to Ask! Road Profile Users Group Meeting. Lincoln, Nebraska, USA.

Haas, R., Hudson, W. R., \& Falls, L. C. (2015). Pavement Asset Management. USA \& Canada: Scrivener Publishing WILLEY. ISBN 978-1-119-03870-2

Horn, W. J. (1977). Airfield Pavement Smoothness Requirements. Technical Report S-77-12. Soils and Pavements Laboratory. U.S. Army Engineer Wterways Experiment Station, Vicksburg, Miss. Washington, D.C., USA.

Houbolt, J. C. (1961). Runway roughness studies in the aeronautical field. ASCE Proceedings. Journal of Air Transport Division, 87(AT 1), 11-31. USA.

Kirk, C. L. (1973). Analysis of Taxiing Induced Vibrations in Aircraft by The Power Spectral Density Method. Cranfield Report Aero No. 15. Structural and Aerospace Dynamics Group, College of Aeronautics. Cranfield Institute of Technology. England.

Morris, G. J., \& Hall, A. W. (1965a). Recent Studies of Runway Roughness. Conference on Aircraft Operating Problems: A Compilation of the Papers Presented. Langley Research Center. National Aeronautics and Space Administration, pp. 1-7.

Morris, G. J., \& Hall, A. W. (1965b). Response of a WB-47E Airplane to Runway Roughness at Eielson Air Force Base. Technical Memorandum SX-1076. Langley Research Center. Langley Station, Hampton, VA. National Aeronautics and Space Administration. Washington, D.C., USA.

NASA. (1992). Issues on Human Acceleration Tolerance After Long-Duration Space Flights. NASA-TM-104753. National Aeronautics and Space Administration. Lyndon B. Johnson Space Center, 55. Houston, Texas, USA.

Sayers, M. W., \& Karamihas, S. M. (1998). The Little Book of Profiling. Basic Information About Measuring and Interpreting Road Profiles. USA: University of Michigan.

Sayers, M. W., \& Karamihas, S. M. (1996). Interpretation of Road Roughness Profile Data. Final Report FHWA-RD-96-10. The University of Michigan Transportation Research Institute. Federal Highway Administration. McLean, VA, USA.

Sayers, M. W., Gillespie, T. D., \& Patterson, W. D. (1986). Guidelines for Conducting and Calibrating Road Roughness Measurements. WORLD BANK TECHNICAL PAPER NUMBER 46. Washington, D.C., USA.

Sayers, M., Gillespie, T. D., \& Queiroz, C. (1986). The International Road Roughness Experiment - Establishing Correlation and a Calibration Standard for Measurements. WORLD BANK TECHNICAL PAPER NUMBER 45. Washington, D.C., USA.

Sayers, M., Gillespie, T. D., \& Queiroz, C. (1984a). International Experiment to Establish Correlation and Standard Calibration Methods for Road Roughness Measurements. UMTRI-84-12-1. The University of Michigan, Transportation Research Institute and Brazil Road Research Institute. The World Bank and Brazil Ministry of Transportation. Brazil.

Sayers, M., Gillespie, T. D., \& Queiroz, C. (1984b). International Experiment to Establish Correlation and Standard Calibration Methods for Road Roughness Measurements - APPENDICES. UMTRI-84-12-2. The University of Michigan, Transportation Research Institute and Brazil Road Research Institute. The World Bank and Brazil Ministry of Transportation. Brazil.

Spangler, E. B., \& Gerardi, A. G. (1993). Measurement and Analysis of Airside Pavement Roughness at the Dallas/Fort Worth International Airport. Airport Pavement Innovations. Theory to Practice. Proceedings of Conference, pp. 329-346. Vicksburg, Mississippi, USA. 